\title{
Problem-based learning model: It's effect on mathematical literacy ability based on students' visual verbal ability
}

\author{
Aulia Syafitri ${ }^{1 *}$, Nizlel Huda ${ }^{1}$, Haryanto ${ }^{1}$ \\ ${ }^{1}$ Universitas Jambi, Indonesia. \\ $\triangle$ auliasyaftri.as02@gmail.com
}

Article Information

Submitted Nov 19, 2021

Revised Dec 11, 2021

Accepted Dec 11, 2021

\section{Keywords}

Problem-Based Learning; Visual Verbal Ability; Mathematical Literacy Ability.

\begin{abstract}
This study was conducted at SMP Negeri 9 Jambi City to determine the effect of the Problem-based Learning (PBL) model on mathematical literacy skills in the Pythagorean Theorem material. The quasiexperimental design was used with a non-equivalent pretest and posttest control group design. The researchers collected the mathematical literacy ability data using a description test instrument. Furthermore, the visualverbal ability data was collected using a visual-verbal ability questionnaire. This research was conducted on the seventh-grade students, with 69 students divided into two classes (experimental and control classes). A random sampling technique determined the sample. Based on the two-way ANOVA test, applying the Problem-based Learning (PBL) model on students' mathematical literacy skills was an effect. There was an effect of visual-verbal ability on literacy skills.
\end{abstract}

\section{INTRODUCTION}

Mathematical literacy is one of the important skills that students must possess (NCTM, 2000; Demir, 2020). Mathematical literacy will give students awareness and understanding of the role of mathematics in the modern world (Bolstad, 2021; Baumgartner et al., 2021; Christiansen, 2006; Kuznetsova, 2021). Mathematical literacy has become a major goal in schools in certain countries. It is stated that the priority of the mathematics curriculum should be mathematical literacy. Now reading, writing, and arithmetic skills are not enough to deal with increasingly complex and difficult problems in everyday life.

In mathematics, students must also understand the relationship between two or more objects (Kuswidi, 2015). Mathematical literacy is very influential in students' mathematical learning achievement (Fair \& Stott, 2021; Federiakin et al., 2021). Mathematical literacy skills include formulating, applying, and interpreting mathematics in various contexts that involve mathematical reasoning, mathematical concepts, procedures, facts, and tools to describe, explain, and predict phenomena related to everyday life (OECD, 2018).

Ideas in mathematics are often interpreted through visual symbols and verbal symbols. The formats of mathematical interpretations can be spoken, pictures, tables, graphs, concrete objects, and other mathematical symbols (Sabirin, 2014). Therefore, verbal and visual skills are needed, especially to support mathematical literacy skills. Verbal skills express students' knowledge and experience in an adequate form of language to communicate to others (Vukovic \& Lesaux, 2013). Visual ability is someone with a cognitive style will be easier to receive, process, store, and process information contained in an image (Bjorling, 2007; Christiansen, 2006). Visual-verbal abilities also need attention from teachers to support 
students' mathematical literacy skills. Visual-verbal abilities will help students understand the model and solve mathematical problems. The better the students' visual-verbal skills, the better their ability to solve problems (Wahyuddin, 2017) .

The relevance of mathematical literacy abilities indicated above does not correspond to Indonesia's achievements on the international stage. According to the Program for International Student Assessment (PISA) findings, Indonesia is ranked lower than other countries. With a score of 379 , Indonesia was ranked $37^{\text {th }}$ out of 42 countries in 2018 (OECD, 2018). According to Indonesia's score, which is at the bottom, the country still has low mathematics literacy skills. At the same time, mathematical literacy abilities are the primary competencies required by pupils to solve mathematical problems, particularly those related to the real world.

The results of the researcher's early observations revealed that the mathematical literacy ability of students in one of Jambi's junior high schools was in a low category. The mathematical literacy ability test results suggest a low level of mathematical literacy ability. Only 26.6 percent of the 30 students given math literacy test questions met the indicators of formulating mathematics, 13.3 percent met the indicators of using mathematics, 6.6 percent met the indicators of interpreting mathematics, and 53.3 percent were unable to meet the indicators of formulating, using, or interpreting mathematics.

Active and effective learning must be designed so that it can aid in the improvement of students' mathematical literacy skills. Problem-based learning is a learning strategy that can be used to develop mathematical literacy abilities. According to Prince (2004), PBL is a learning strategy in which relevant problems are provided at the start of learning and used to create context and motivation for students to learn. Real-life challenges enable students to take an active role in their learning by encouraging them to look for data, think about design solutions, and solve problems (Meke et al., 2018).

PBL can naturally shape students' thinking activities and help students solve their learning problems (Suparman et al., 2021; Salim \& Prajono, 2018). Furthermore, this learning paradigm necessitates that students conduct research, integrate theory and practice, and use knowledge and abilities to generate answers to specific challenges (Savery, 2006). PBL encourages students to solve problems and produce new meaningful knowledge (Kilroy, 2004; Hung et al., 2008). PBL learning contains the following stages: (1) integrating students into real-world situations, (2) organizing students for learning, (3) encouraging students to discover problems, (4) developing and presenting work results, (5) encouraging students to examine and evaluate problem-solving processes (Strobel \& Van Barneveld, 2009; Aufa et al., 2021; Juandi \& Tamur, 2021)

According to several studies, the PBL model can improve students' critical thinking skills in problem-solving (Aufa et al., 2021; Juandi \& Tamur, 2021) because PBL can help students think rationally and orderly, which aims to understand the relationship between ideas and facts in real life (Krzic et al., 2020; Mudrikah, 2016; Geitz et al., 2016; Kim, 2016; Hazrati \& Gavgani, 2016; Ramstedt et al., 2016; Tano, 2021). If students' critical thinking skills improve due to PBL learning, it is intended that PBL will also improve students' mathematical literacy skills. However, according to research by Hanum et al., (2019), this study intends to close this gap by overcoming low mathematical literacy skills with the PBL approach and assessing students' mathematical literacy skills based on visual-verbal abilities. 
There has been no research that has examined mathematical literacy skills based on students' visual-verbal ability.

\section{METHODS}

This is an experimental study with non-equivalent pretest and posttest control groups. The random sampling technique was used to select the experimental and control classes. The researcher chose the two classes because they were not superior classes, and the same teacher taught them. The PBL learning took place over the course of six meetings. At the first meeting, an initial test of mathematical literacy skills was administered to determine the initial ability of students' mathematical literacy. Following that, a visual-verbal ability questionnaire was administered to each class to collect data on students' visual-verbal abilities. Then, both classes were treated, with the experimental class using problem-based Learning and the control class using traditional learning. Students in the experimental class used student worksheet media created using the PBL model, but students in the control class didn't get student worksheet media.

The participants in this study were students from SMP Negeri 9 in Jambi City. The sample consisted of 35 students from class VIIIE as the experimental class and 34 students from class VIIIG as the control class. The sample was assessed for normality and homogeneity using SPSS 25 software with a significance value of 0.05 . The significant value of the experimental class was 0.200 , while the control class was 0.198 based on the normality test. As a result, both samples have a normal distribution and both classes are from the same population (homogeneous).

In this study, questionnaires and tests were employed as instruments. The questionnaire utilized was a visual-verbal ability questionnaire with 18 items that employ a Likert scale to collect the data. Furthermore, the test instrument was in the form of a three-question description test of mathematical literacy skills. The test questions were designed in line with the indicators of mathematical literacy ability to determine students' mathematical literacy ability. The Pythagorean Theorem was the subject matter. Before administering the literacy ability test, a prerequisite test was performed to determine the validity, reliability, level of difficulty, and discriminating index. The instrument was declared valid and reliable based on the validity and reliability tests. The level of difficulty and discriminating index were adequate. This study implemented the two-way ANOVA test for hypothesis testing and the Tukey follow-up test to determine the mean difference of the dependent variable between the two sets of data. The research steps depicted in Figure 1 are as follows: 


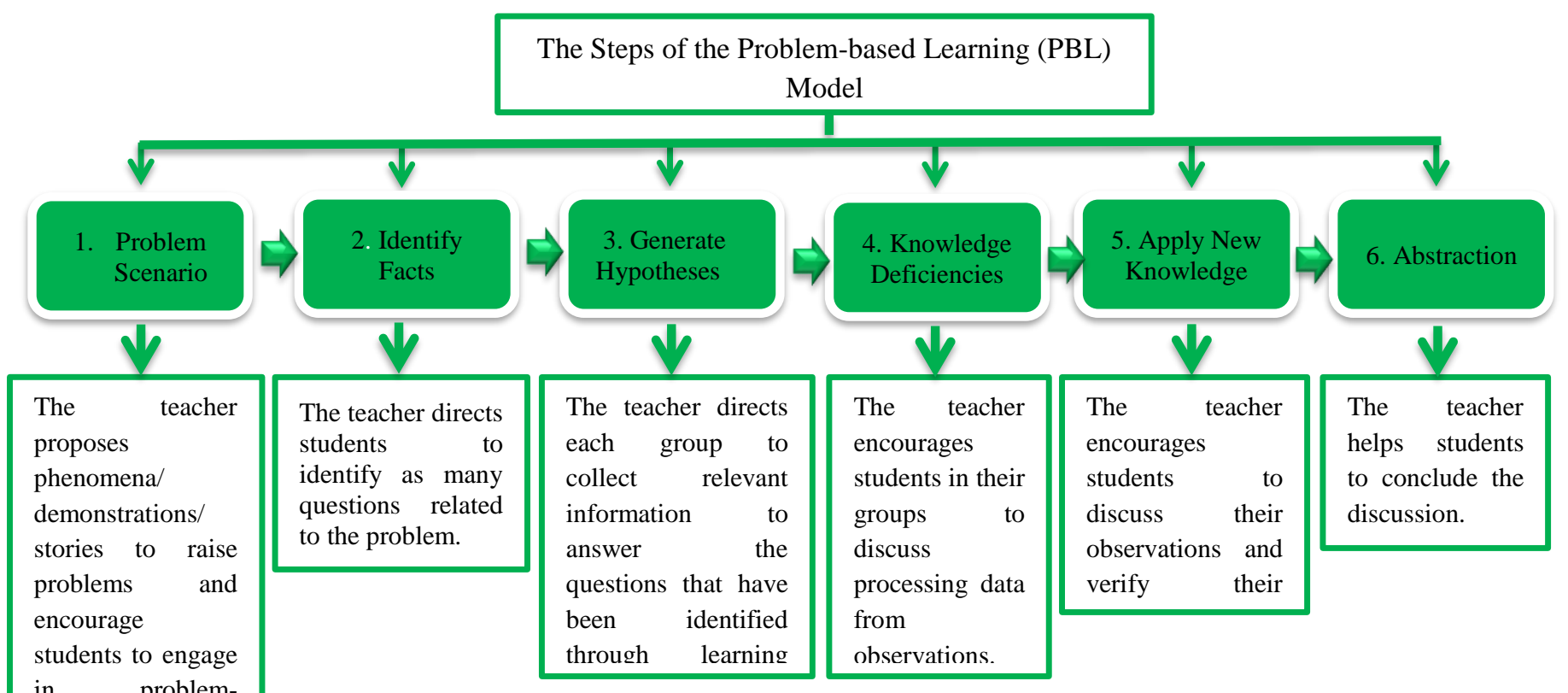

Figure 1. Problem-based Learning (PBL) Steps

\section{RESULTS AND DISCUSSION}

This study collected data on students' visual-verbal abilities and their mathematical literacy skills on Pythagorean theorem material. Data were collected from both the experimental and control groups. A visual-verbal ability questionnaire was used to collect data on students' visual-verbal abilities, and the outcomes of those abilities are shown in Figure 1 below:

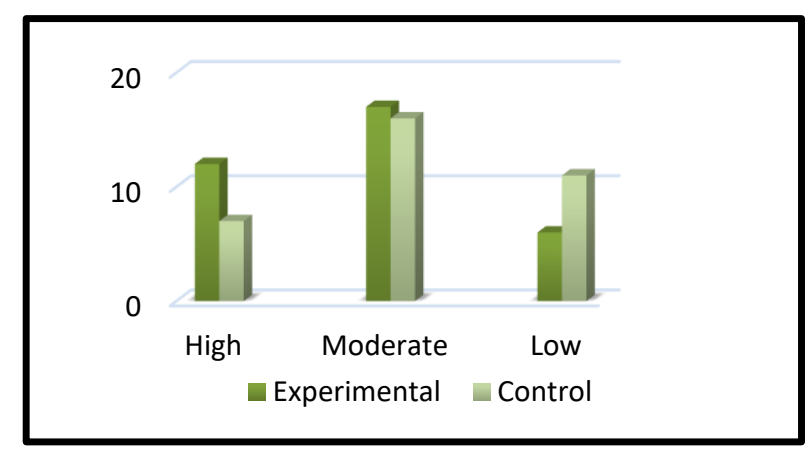

Figure 2. The Frequency Distribution of Students' Visual Verbal Ability

Figure 2 shows that the experimental students' verbal and visual abilities were greater than those of the control students. The data on mathematical literacy skills collected by tests, specifically the pretest (before treatment) and posttest (after treatment), can be seen in Table 1.

Table 1. Mathematical Literacy Ability Data

\begin{tabular}{clcccccc}
\hline Data & Model & P & Mean & SD & Min & Max & Max score \\
\hline \multirow{2}{*}{ Pretest } & Experimental & 35 & 6.88 & 3.79 & 1 & 14 & \multirow{2}{*}{30} \\
& Control & 34 & 6.52 & 3.75 & 1 & 14 & \multirow{2}{*}{30} \\
\hline \multirow{2}{*}{ Posttest } & Experimental & 35 & 17.2 & 7.05 & 5 & 29 & 21 \\
& Control & 34 & 10.94 & 5.3 & 2 & & \\
\end{tabular}


Table 1 shows the results of the pretest and posttest data analysis. Based on the statistics, it is known that the experimental class's average pretest and posttest scores are greater than the control class's average scores. Furthermore, Figures 2 and 3 show the frequency distribution of mathematical literacy abilities in the experimental and control classes:
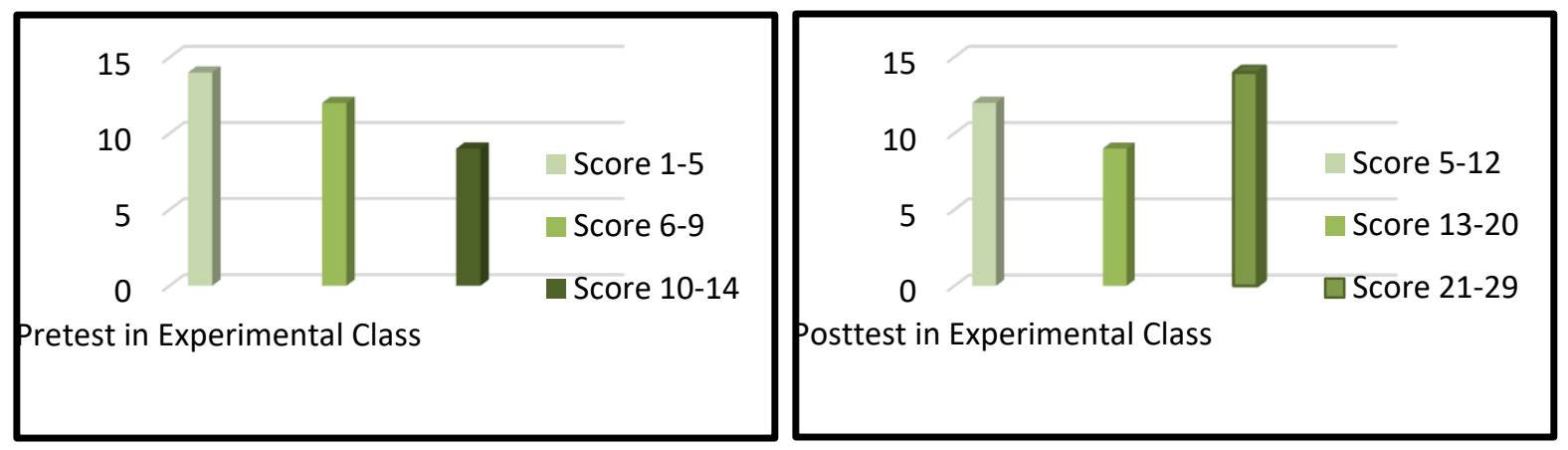

Figure 3. Frequency Distribution of Students' Mathematical Literacy Ability in the PBL Model
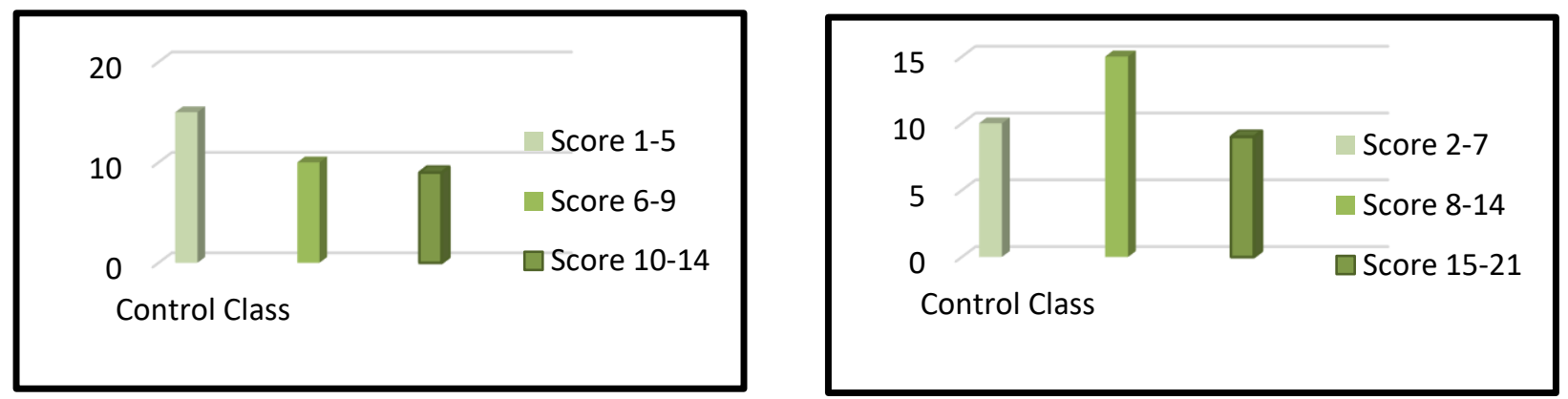

Figure 4. Frequency Distribution of Students' Mathematical Literacy Ability in Conventional Learning

Figures 3 and 4 show that the average pretest and posttest in the experimental class are higher, but the pretest and posttest scores are also higher. There is a substantial increase between the experimental class's pretest and posttest scores.

The two-way ANOVA test on the first hypothesis obtained a significance value of 0.000 (lower than 0.05). Therefore, $H_{1}$ was accepted, and $H_{0}$ was rejected. It can be concluded that there was an effect of the Problem-based Learning (PBL) model on students' mathematical literacy abilities. The two-way ANOVA test on the second hypothesis obtained a significance value of 0.000 (lower than 0.05 ). Therefore, $H_{1}$ was accepted, and $H_{0}$ was rejected. It can be concluded that there was an effect of the high visual-verbal ability, medium visual-verbal ability, and low visual-verbal ability on students' mathematical literacy skills. Because $H_{0}$ was rejected, the researchers continued the testing with the Tukey test. The results are as follows:

Table 2. Tukey Test

\begin{tabular}{ccc}
\hline Visual-verbal skills & N & Subs 1 \\
\hline Low & 25 & 6.48 \\
Medium & 49 & 14.53 \\
High & 29 & 23.38 \\
Sig & & 1,000 \\
\hline
\end{tabular}

Table 2 shows that high and moderate visual-verbal abilities are more effective than low visual-verbal abilities. This study showed that students with high and moderate visual-verbal 
abilities are better than students with low visual-verbal abilities in terms of mathematical literacy skills.

Table 3. PBL learning activities on mathematical literacy skills

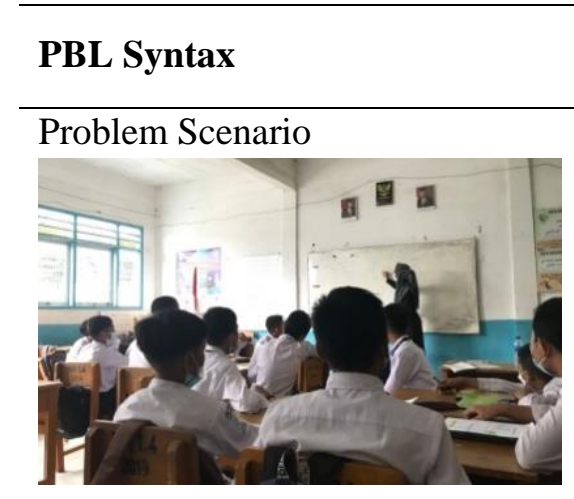

Identify Fact

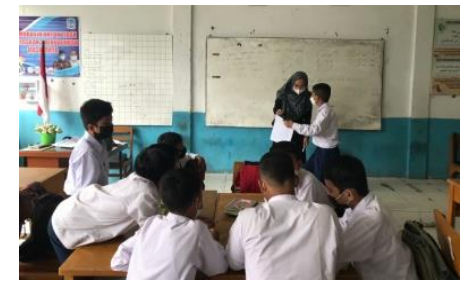

Generate Hypotheses

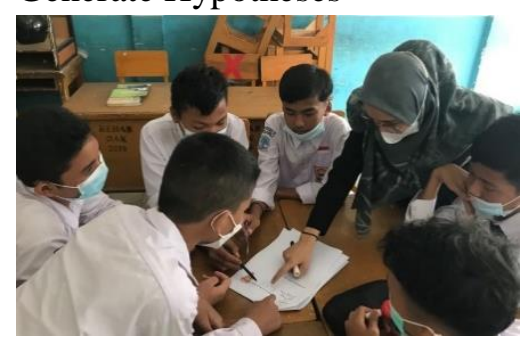

Knowledge Deficiencies
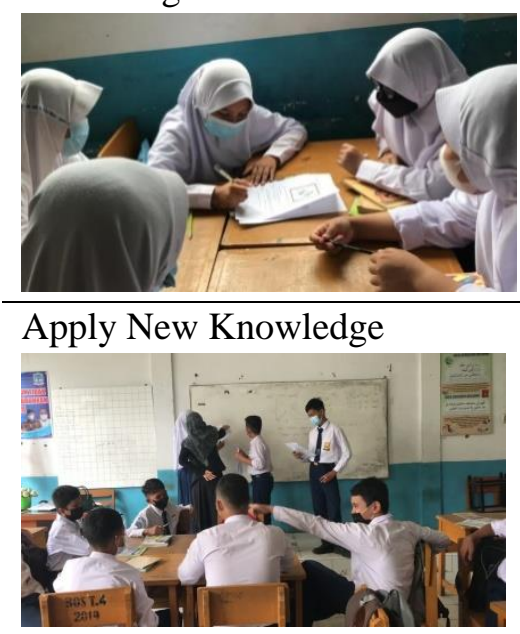

Abstraction

\section{Activity}

Propose a phenomenon or demonstration to raise a problem.

Identify as many questions as possible related to the problem.
Indicator of Mathematical Literacy ability

\section{Formulate:}

a) Identify the mathematical aspects of the problem in a realworld context and the variables seen in the problem.

b) Simplify a situation or problem to make it mathematically analyzable.
Collect relevant information to answer the identified questions identified through learning activities

Students discuss data processing based on observations.
Use:

a) Design and implement strategies to find mathematical solutions.

b) Apply mathematical facts, rules, algorithms, and structures when looking for solutions.
Students discuss and verify the results of their
observations by writing
answers in front of the class.
The teacher and students discuss to conclude the lesson.
a) Interprete mathematical results back into a real-world context.
b) Evaluate the reasonableness of mathematical solutions in the context of real- world problems. 


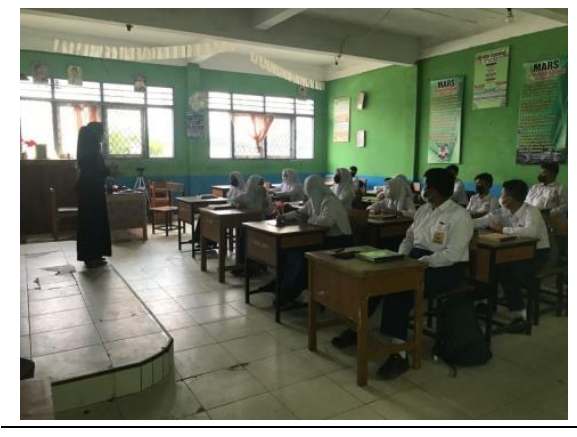

c) Explain why mathematical results or conclusions make sense or do not fit the context of the problem.

The PBL significantly influenced students' mathematical literacy skills (Fery et al., 2017; Kane et al., 2016). The PBL model influenced students' mathematical literacy abilities based on the two-way ANOVA test. The PBL stages encourage students to build their knowledge, improve skills, and develop critical thinking. The results are in line with the research results conducted by (Karyatin, 2017) that PBL can improve students' skills in constructing mind maps. Table 4 presents students' different answers between the experimental and control classes.

Table 4. Example of Student Answers from the Experimental Class and the Control Class

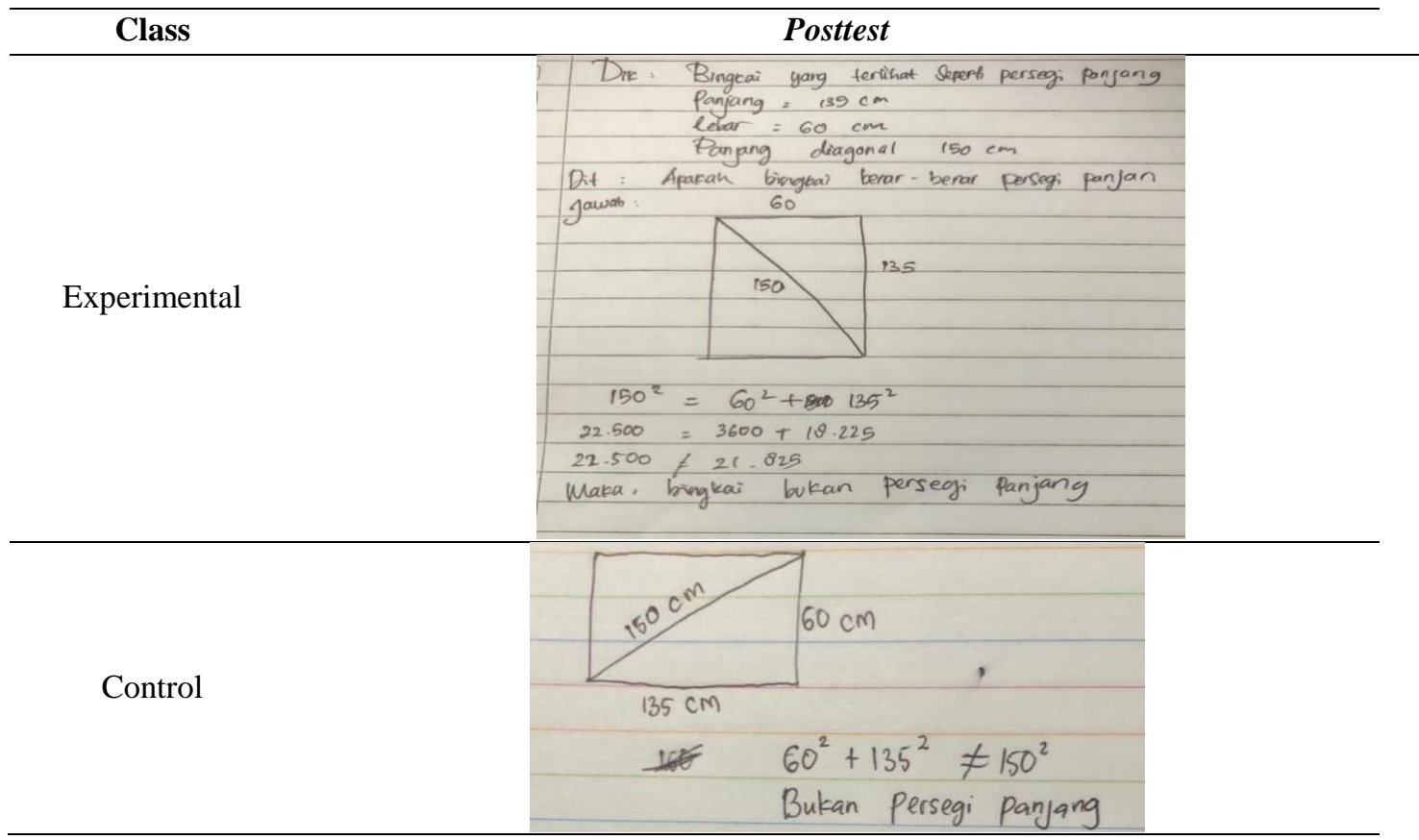

Table 4 compares and contrasts the posttest responses of students in the experimental class and students in the control class. Before treatment, the students were still incorrect in answering pretest questions. They were unable to appropriately formulate, design, or interpret problems. There was an increase in students' literacy skills when working on the posttest after receiving treatment using different models in the two classes. Students in the experimental class, on the other hand, offered more structured and full replies than students in the control class. Students in the experimental class correctly formulated mathematical problems, devised strategies for locating appropriate answers and reinterpreted mathematical findings in realworld contexts. 
The PBL model helps students develop the ability to understand mathematical concepts, mathematical representation, mathematical reasoning, communication and mathematical connections, contextual problem-solving, and non-routine questions, all of which fall under the scope of mathematical literacy skills (Tabun et al., 2020).

Students in the experimental class outperformed students in the control class in both visual and verbal abilities. Students with strong visual-verbal skills can effectively represent answers. Students' ability to express concepts fluently improves due to their strong verbal and visual abilities (Kumara, 2001; Gordon et al., 2021; Dehaene, 1999) state that several components of number processing, such as reading, writing, and manipulating symbols, are heavily reliant on verbal skills. As a result, visual ability can be a valuable cognitive tool in problem-solving in mathematics. It is a key talent in learning, applying, and developing students' positive characters (Zhang, 2019; Surya, 2012).

\section{CONCLUSIONS}

According to the findings, the Problem-based Learning (PBL) approach affected students' mathematical literacy abilities. There was also an influence of students' verbal-visual abilities on mathematical literacy abilities, as indicated by the average value of students in the experimental class and the results of the two-way ANOVA test, which showed that the significant value was less than 0.05 . This suggests that the PBL paradigm has an impact on mathematical literacy skills. According to the Tukey test, kids with high and moderate visualverbal abilities have superior mathematical literacy skills than students with low visual-verbal abilities.Based on the discussion, it is hoped that other researchers would not make conceptual errors in the learning process while employing the Problem-based Learning (PBL) model. They must assess students' visual-verbal abilities through testing and make the required efforts to improve them.

\section{AUTHOR CONTRIBUTIONS STATEMENT}

AS is the research coordinator who contributed to developing theory as well as analyzing data and $\mathrm{NH}$ is responsible for designing research instruments and selecting methods to be used.

\section{REFERENCES}

Aufa, M. N., Rusmansyah, R., Hasbie, M., Jaidie, A., \& Yunita, A. (2021). The effect of using e-module model problem based learning (PBL) based on wetland environment on critical thinking skills and environmental care attitudes. Jurnal Penelitian Pendidikan IPA, 7(3), 401-407.

Baumgartner, W. L., Spangenberg, E. D., \& Lautenbach, G. V. (2021). Developing algebraic knowledge: Foundation programme ex-mathematical literacy students' perceptions. Eurasia Journal of Mathematics, Science and Technology Education, 17(11), 2026.

Björling, F. (2007). Contemporary narrative under the impact of visual culture. McEwan's Saturday

Bolstad, O. H. (2021). Lower secondary students' encounters with mathematical literacy. Mathematics Education Research Journal, 1-17.

Christiansen, I. M. (2006). Mathematical literacy as a school subject: Failing the progressive vision?. Pythagoras, 12(1), 6-13.

Dehaene, S., Spelke, E., Pinel, P., Stanescu, R., \& Tsivkin, S. (1999). Sources of 
mathematical thinking: Behavioral and brain-imaging evidence. Science, 284(5416), 970-974.

Demir, F. (2020). Mathematics literacy curriculum design based on question writing. International Journal of Education Technology and Scientific Researches, 5(11), 35-62.

Fair, D. L., \& Stott, A. E. (2021). A Longitudinal case study of mathematics and mathematical literacy achievement of boys at a high quintile school in South Africa. African Journal of Research in Mathematics, Science and Technology Education, 1-11.

Federiakin, D. A., Larina, G. S., \& Kardanova, E. Y. (2021). Measuring basic mathematical literacy in elementary school. Voprosy Obrazovaniya, 2021(2), 199-226.

Fery, M. F., Wahyudin, \& Tatang, H. (2017). Improving primary students mathematical literacy through problem based learning and direct instruction. Educational Research and Reviews, 12(4), 212-219.

Geitz, G., Joosten-ten Brinke, D., \& Kirschner, P. A. (2016). Are marketing students in control in problem-based learning? Cogent Education, 3 (1), 1-15..

Gordon, R., Smith-Spark, J. H., Newton, E. J., \& Henry, L. A. (2021). Children's Verbal, Visual and Spatial Processing and Storage Abilities: An Analysis of Verbal Comprehension, Reading, Counting and Mathematics. Frontiers in Psychology, 5671.

Hanum, L., Istikomah, D. A., \& Jana, P. (2019). Perbandingan model pembelajaran problem based learning (PBL) dan discovery learning (Dl) ditinjau dari kemampuan pemecahan masalah. Eduma: Mathematics Education Learning and Teaching, 8(1), 67-74.

Hazrati, H., \& Gavgani, V. Z. (2016). Which levels of education in medical sciences utilize most the Problem Based Learning? A citation analysis study. Library Philosophy and Practice, 2016(1).

Hung, W., Jonassen, D. H., \& Liu, R. (2008). Problem-based learning. In Handbook of research on educational communications and technology (pp. 485-506). Routledge.

Juandi, D., \& Tamur, M. (2021). Problem-based learning for mathematical critical thinking skills: A meta-analysis. Journal of Hunan University (Natural Sciences),48(2), 133-144.

Kane, S. N., Mishra, A., \& Dutta, A. K. (2016). Preface: International conference on recent trends in physics (ICRTP 2016). Journal of Physics: Conference Series, 755(1), 0-5.

Karyatin, K. (2017). Penerapan modified problem based learning (PBL) dengan gallery walk (GW) untuk meningkatkan keterampilan menyusun peta pikiran dan hasil belajar IPA. Jurnal Penelitian Pendidikan IPA, 1(2), 42-51.

Kilroy, D. A. (2004). Problem based learning. Emergency Medicine Journal, 21(4), 411-413.

Kim, M. S. (2016). Development and effect of a web-based problem-based learning system for an accounting course in engineering education. World Transactions on Engineering and Technology Education, 14(3), 394-403.

Krzic, M., Brown, S., \& Bomke, A. A. (2020). Combining problem-based learning and teambased learning in a sustainable soil management course. Natural Sciences Education, 49(1), 1-31.

Kumara, A. (2001). Dampak kemampuan verbal terhadap kualitas ekspresi tulis. Jurnal Psikologi, 28(1), 35-40.

Kuswidi, I. (2015). Brain-based learning untuk meningkatkan literasi matematis siswa. AlJabar : Jurnal Pendidikan Matematika, 6(2), 195-202.

Kuznetsova, I. V. (2021). Web-technologies in Knowledge Integration as a Means of Mathematical Literacy Forming of School Students. Turkish Journal of Computer and Mathematics Education (TURCOMAT), 12(10), 1578-1586.

Meke, K. D. P., Wutsqa, D. U., \& Alfi, H. D. (2018). The effectiveness of problem-based learning using manipulative materials approach on cognitive ability in mathematics learning. Journal of Physics: Conference Series, 1097(1), 0-6.

Mudrikah, A. (2016). Problem-based learning associated by action-process-object-schema 
(APOS) theory to enhance students' high order mathematical thinking ability. International Journal of Research in Education and Science, 2(1), 125-135.

NCTM. (2000). NCTM. Journal of Equine Veterinary Science, 18(11).

OECD. (2018). PISA for development assessment and analytical framework: Reading, mathematics and science. OECD..

Prince, M. (2004). Does active learning work? A review of the research. Journal of Engineering Education, 93(7), 223-231.

Ramstedt, M., Hedlund, T., Björn, E., Fick, J., \& Jahnke, I. (2016). Rethinking chemistry in higher education towards technology-enhanced problem-based learning. Education Inquiry, 7(2).

Sabirin, M. (2014). Representasi dalam pembelajaran matematika. Jurnal Pendidikan Matematika, 1(2), 33-44.

Salim, \& Prajono, R. (2018). Profil kemampuan literasi matematis siswa kelas VIII SMP Negeri 9 Kendari. Indonesian DIgital Journal of Mathematics and Education, 5(9), 594-602.

Savery, J. R. (2006). Overview of problem-based learning: Devinition and distinction interdisciplinary. Journal Problem-Based Learning, 1(1), 9-20.

Strobel, J., \& van Barneveld, A. (2009). When is PBL more effective? A meta-analyses comparing PBL to conventional classrooms. Interdisciplinary Journal of ProblemBased Learning, 3(1), 44-58.

Suparman, S., Juandi, D., \& Tamur, M. (2021). Does problem-based learning enhance students' higher order thinking skills in mathematics learning? A systematic review and meta-analysis. ACM International Conference Proceeding Series, 44-51.

Surya, E. (2012). Visual thinking dalam memaksimalkan pembelajaran matematika siswa dapat membangun karakter bangsa. Jurnal Penelitian dan Pembelajaran Matematika, 5(1), 41-50.

Tabun, H. M., Taneo, P. N. L., \& Daniel, F. (2020). Kemampuan literasi matematis siswa pada pembelajaran model problem based learning (PBL). Edumatica: Jurnal Pendidikan Matematika, 10(01), 1-8.

Tano, M. (2021). Problem based learning: An active method for the teaching of languages for specific purposes. [L'apprentissage par problèmes: Une méthode active d'enseignement des langues étrangères pour spécialistes d'autres disciplines].

Vukovic, R. K., \& Lesaux, N. K. (2013). The relationship between linguistic skills and arithmetic knowledge. Learning and Individual Differences, 23(1), 87-91.

Wahyuddin, W. (2017). Analisis kemampuan menyelesaikan soal cerita matematika ditinjau dari kemampuan verbal. Beta Jurnal Tadris Matematika, 9(2), 148-160.

Zhang, S., Xia, X., Li, F., Chen, C., \& Zhao, (2021). Study on visual and auditory perception characteristics of children with different type of mathematics learning disability. International Journal of Disability, Development and Education, 68(1), 78-94. 